\title{
Defining type 2 asthma and patients eligible for dupilumab in Italy: a biomarker-based analysis
}

\author{
Giorgio Walter Canonica ${ }^{1,2}$, Francesco Blasi ${ }^{3}$, Nunzio Crimii ${ }^{4,5}$, Pierluigi Paggiaro ${ }^{6}$, Alberto Papi ${ }^{7}$, \\ Francesca Fanelli ${ }^{8}$, Annalisa Stassaldi ${ }^{8}$ and Gianluca Furneri ${ }^{9^{*}}$ (D)
}

\begin{abstract}
Background: Asthma is a chronic disease characterized by airway hyperresponsiveness, inflammation and mucus production. In Type 2 asthma, two phenotypic components are often co-expressed (eosinophilic and allergic). Elevated biomarker levels, such as eosinophils (EOS), fraction of exhaled nitric oxide (FeNO) and immunoglobulin E (IgE), are key clinical indicators of Type 2 inflammation. Dupilumab has been recently approved for the treatment of uncontrolled severe Type 2 asthma. Type 2 asthma includes allergic and/or eosinophilic phenotypes. The aim of this analysis was to estimate the dupilumab-eligible population in Italy and characterize it by expected biomarker status.

Methods: A 4-step approach was carried out to calculate dupilumab-eligible population. The approach consisted in: (1) estimating the total number of asthma patients in Italy (using 2016-2017 Italian-adapted Global Initiative for Asthma -GINA- guidelines); (2) estimating the number of severe asthma patients with poorly controlled or uncontrolled disease (using the findings of two recent administrative claim analyses conducted in Italy); (3) stratifying the severe uncontrolled population by biomarker levels (EOS, FeNO and $\lg E$ ) according to the outcomes of the QUEST trial (a clinical study assessing the efficacy of dupilumab in patients with uncontrolled moderate-to-severe asthma; NCT02414854); (4) identifying the sub-populations of severe uncontrolled asthma patients characterised by raised blood EOS and/or FeNO level (thus indicated to receive dupilumab).
\end{abstract}

Results: According to these estimates, about 3.3 million asthmatic patients live in Italy (6.10\% of the population). Of them, almost 20 thousand $(N=19,960)$ have uncontrolled severe asthma. Dupilumab-eligible patients would be $N=15,988$, corresponding to $80.1 \%$ of the total uncontrolled severe population. Most of these patients (89.3\%; $N=14,271)$ have at least an increase of EOS level, while slightly more than half $(51.9 \% ; N=8,303)$ have raised levels of both biomarkers. Increased FeNO levels without increased EOS are observed less frequently $(N=1,717 ; 10.7 \%$ of the eligible population).

Conclusions: There is a strong rationale for testing all asthma biomarkers during diagnosis and disease follow-up. Given the large availability and the limited costs, these tests are cost-effective tools to detect severe Type 2 asthma, stratify patients by phenotype, and drive appropriate treatment decisions.

Keywords: Type 2 asthma, Dupilumab, Biomarkers, Italy

*Correspondence: gianluca.furneri@ebmaconsulting.com

${ }^{9}$ EBMA Consulting S.R.L., Via per Carpiano 2, 20077 Melegnano, MI, Italy

Full list of author information is available at the end of the article

\section{Introduction}

Asthma is a chronic disease affecting people of any age characterized by airway hyperresponsiveness (AHR), airway obstruction and inflammation, intermittent airflow

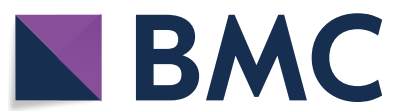

(c) The Author(s) 2021. This article is licensed under a Creative Commons Attribution 4.0 International License, which permits use, sharing, adaptation, distribution and reproduction in any medium or format, as long as you give appropriate credit to the original author(s) and the source, provide a link to the Creative Commons licence, and indicate if changes were made. The images or other third party material in this article are included in the article's Creative Commons licence, unless indicated otherwise in a credit line to the material. If material is not included in the article's Creative Commons licence and your intended use is not permitted by statutory regulation or exceeds the permitted use, you will need to obtain permission directly from the copyright holder. To view a copy of this licence, visit http://creativeco mmons.org/licenses/by/4.0/. The Creative Commons Public Domain Dedication waiver (http://creativecommons.org/publicdomain/ zero/1.0/) applies to the data made available in this article, unless otherwise stated in a credit line to the data. 
and mucus production [1, 2]. Wheezing, cough, chest tightness, and shortness of breath, usually accompanied by airflow limitation, are the most typical symptoms of asthma patients [1]. Asthma is also a common condition: recent estimates report that about 300 million people have asthma worldwide, with prevalence of the disease likely increasing by a further 100 million by 2025 [3-6].

The way asthma has been defined and classified has changed over time. In the past, asthma was considered "a single entity" disease, characterized by abnormal response of T-helper cell Type 2 (Th2) cells and B cells [7]. Today, the term "asthma" is rather intended as a collection of several distinct endotypes (T2-high vs T2-low) and phenotypes (e.g. young atopic, obese middle aged, smokers, late onset, etc.) that can lead to different symptomatology and variable level of airflow obstruction [7]. Particularly in severe asthma, in-depth understanding of asthma pathogenesis and pathophysiology, together with identification of phenotypes, has important implications on treatment decision making.

The pathophysiology of asthma is characterized by the immune response of two CD4+ T-cell subsets, Th1 and Th 2 cells. Specifically, the Type 2 asthma endotype (in the past known as "T2-high") is originated from the complex mechanisms of Type 2 inflammation where two phenotypic components are co-expressed (eosinophilic, allergic, or mixed). Type 2 inflammation is mainly driven by Th2 cell activation, which triggers an abnormal generation of cytokines (interleukin IL-4, IL-5 and IL-13), in response to the detection of different agents (e.g. allergens, pollution, viruses, etc.) $[1,7,8]$. Indeed, further research in the last decades clarified that the underlying mechanism of Type 2 inflammation is much more complex, being mediated by many other players, such as innate lymphoid cells (ILC2s), produced in response to external agents $[1,7,8]$. Th2 and ILC2-derived IL-4, IL-5, and IL-13 generate the typical pathophysiological effects of asthma, including activation and recruitment of eosinophils in the airways, IgE production by activated plasma cells, AHR and airway remodelling.

IL-4 and IL-13 are relatively upstream players in the inflammatory cascade, and they are responsible for various pro-inflammatory activities. IL-13 stimulates the production of eotaxin 1 in airway inflammatory cells, causes airway smooth muscle and goblet cell hyperplasia, transforms fibroblasts into myofibroblasts, increases tracheal-bronchial mucus secretion, collagen production by fibroblasts and subepithelial basal membrane thickening, which are all features of airway remodelling [9]. IL-4 plays a central role in the activation of the whole cytokine cascade in Type 2 inflammation. It acts on mast cells, producing IL-4/13 and IL-5 themselves. Furthermore, IL-4/13 induce isotype class switching of B cells to produce IgE, and directly affect the lung airway structure. In particular, IL-4/13 induce basement membrane thickening, impairment of epithelial integrity and proliferation of M2 macrophages, which directly changes the lung airway structure (e.g. fibrosis). Finally, IL-13 promotes inducible nitric oxide (iNO)-synthase activity and nitric oxide (NO) production, increasing the fraction of exhaled nitric oxide (FeNO) level (Fig. 1).

Type 2 is probably the most common type of asthma: about $50 \%-70 \%$ of people with asthma have an underlying Type 2 inflammation $[8,10,11]$. From a diagnosis

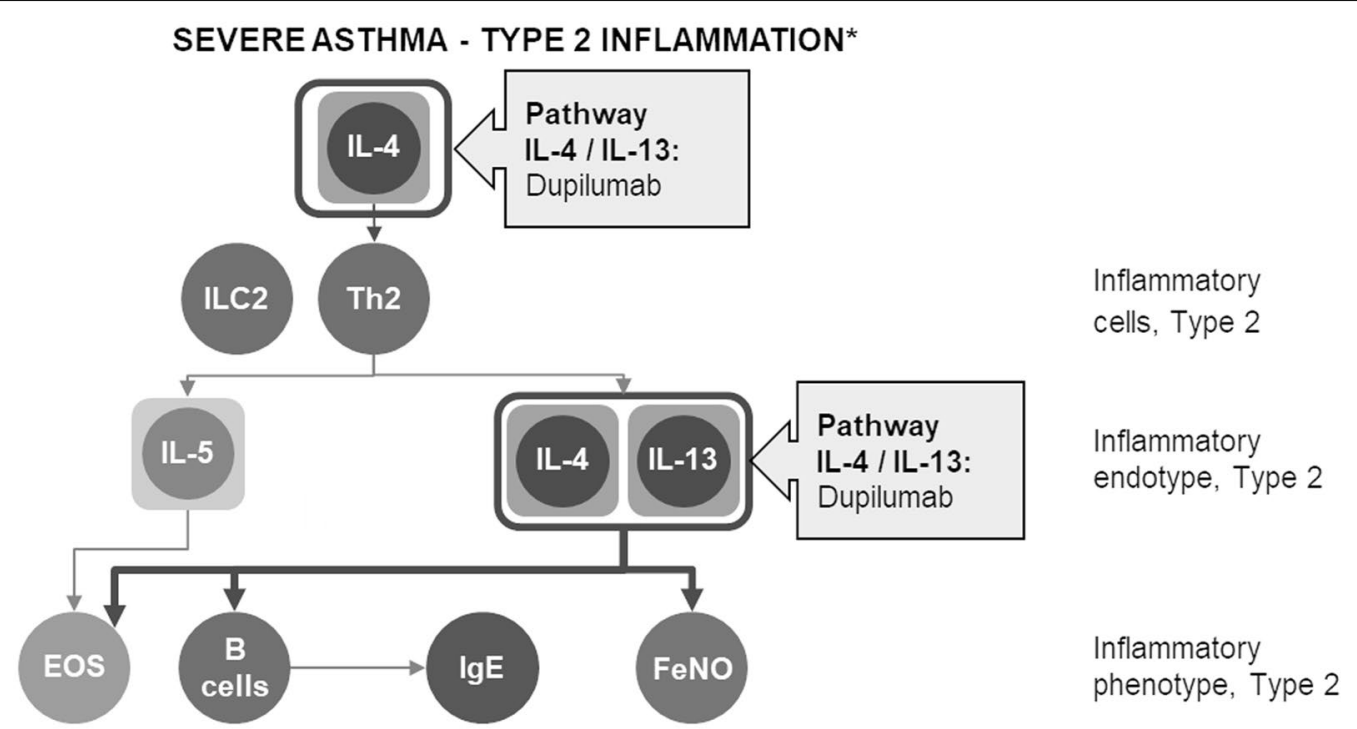

Fig. 1 Pathophysiology of Type 2 inflammation in severe asthma. IL-4 /IL-13 pathway. IL-5 pathway 
standpoint, blood eosinophils (EOS) count has been commonly used as a biomarker to identify Type 2 asthma. Indeed, other biomarkers, such serum immunoglobulin-E (IgE) levels, and more recently FeNO, have been linked to mechanisms involved in Type 2 inflammation $[1,12,13]$. More specifically, FeNO has emerged as an important biomarker, as it informs about the inflammatory state of the airways $[9,14]$. Therefore, it has been effectively used as predictive biomarker in several clinical trials evaluating the effectiveness of biological therapies in moderate-severe asthma [15-18]. Furthermore, during the process of allergic inflammation, FeNO is produced by the airway epithelium in excessive amount, because of the nitric oxide synthase upregulation, so elevated FeNO is a good index of Type 2 inflammation.

Elevated biomarker levels, such as EOS, FeNO and IgE, are key clinical indicators of Type 2 inflammation $[11,19]$. EOS level is mediated by IL-4, IL-13, and IL-5 and defines eosinophilic asthma [20, 21]. FeNO level correlates with serum IgE and sputum EOS; it is mediated by IL- 4 and IL-13 [22], and correlates also with allergic asthma [20, 21]. Type 2 inflammation is the key driver of all Type 2 asthma phenotypes, including eosinophilic, allergic or mixed (i.e. eosinophilic and allergic are coexpressed) [21].

Today, clinical guidelines recommend testing severe asthma patients for multiple biomarkers, i.e. blood and sputum EOS, FeNO, IgE (thresholds: blood EOS $\geq 150$ cells $/ \mu \mathrm{L} ; \mathrm{FeNO} \geq 20 \mathrm{ppb} ; \mathrm{IgE} \geq 30 \mathrm{IU} / \mathrm{mL}$ ) especially in presence of refractory disease with underlying Type 2 inflammation [1]. There is a clear rationale for investigating these biomarkers simultaneously: while in many patients more than one biomarker can be overexpressed, others could have only one increased, independently one from the other [7]. In this latter case, some biomarker expression might have been suppressed by pharmacological treatment, (i.e. oral corticosteroids for blood eosinophils) but asthma would remain clinically uncontrolled $[1,23]$.

Evaluation of Type 2 inflammation biomarkers is of critical importance to guide treatment decision in severe asthma which is refractory to conventional medical therapy. The standard of care of asthma is based on inhaled corticosteroids (ICS), either as monotherapy or in combination with other treatments, such as long-acting 32-adrenoreceptor agonists (LABAs) and/or cysteinylleukotriene type 1 receptor antagonists (LTRAs) [1, 23]. However, treatment is estimated to be ineffective in around $5 \%-10 \%$ of the overall population (i.e. severe patients), who then need escalation to high dose ICS and/or systemic therapy with corticosteroids, associated with uncertain clinical response, high risk of adverse events and long-term contraindications [1, 23, 24]. It is estimated that asthma is not adequately controlled in about half of this severe, refractory population [25]. Furthermore, the clinical picture can be complicated by coexisting Type 2 inflammatory conditions that are commonly observed in these patients: chronic rhinitis and sinusitis, nasal polyps, atopic dermatitis [26].

Over the last 15-20 years, several biologic therapies have been developed to address the unmet medical need in severe asthma, and many others are under evaluation in clinical trials [27]. Treatment with biologic therapies has improved the prognosis of patients with uncontrolled severe asthma, and concomitantly, the understanding of the complex pathogenesis and pathophysiology mechanisms of the disease, favouring the concept of patient stratification by biomarker [27]. Among biologics, dupilumab (Dupixent), a fully human monoclonal antibody directed against the alpha subunit of the IL-4 receptor (and inhibiting IL-4 and IL-13 signalling) has been shown to be safe and effective in adolescents and adults with severe uncontrolled asthma [28-30]. Recently, dupilumab has been authorized by the European Medicines Agency (EMA) for the "treatment of adults and adolescents 12 years and older as add-on maintenance treatment for severe asthma with Type 2 inflammation, characterised by raised blood EOS and/or raised FeNO" [31]. Therefore, dupilumab is the first biologic approved and specifically indicated for the treatment of uncontrolled severe asthma with Type 2 inflammation: asthma that includes allergic (anti-IgE) and/or eosinophilic (anti-IL5) phenotypes. Instead, the other biologic drugs approved by the EMA are indicated for specific Type 2 severe asthma phenotypes (e.g. "Allergic" for anti-IgE or "Eosinophilic" for anti-IL5) [32-36]. The rationale for this biomarker-related indication comes from the QUEST study, a 52-week placebo-controlled, phase 3 confirmatory study (NCT02414854) enrolling patients aged $\geq 12$ years, one of the largest ever-conducted trials characterizing patients in terms of biomarker expression (EOS, FeNO, IgE).

Stratification of patient population by biomarkers to identify the right eligible patients is a crucial task in the "biologic-era". While personalized treatment of asthma is producing significant benefits for patients, asthma management costs are increasing. Notably, about $50 \%$ of the global asthma budget is allocated to severe patients (who account for $<10 \%$ of the overall population) $[37,38]$.

The need for managing resources appropriately and controlling therapeutic expenditure makes biomarker testing even more important, for budget allocation purposes and cost-effective use of high-cost drugs, such as biologics. Quite recently, many studies have been conducted with the objective of estimating the epidemiological and clinical burden of severe asthma in Italy [39-41]. 
In this paper we aimed to: (1) estimate the number of Type 2 severe asthma patients who would be eligible for dupilumab treatment in Italy, according to its approved indication; and (2) characterize the dupilumab-eligible population by expected biomarker status.

\section{Methods}

This paper aims to calculate the number of Type 2 severe asthma patients who would be eligible for dupilumab treatment in Italy.

A 4-step approach was used: (1) estimation of the total number of asthma patients (overall asthma population); (2) estimation of the number of severe asthma patients, who are poorly controlled or uncontrolled (despite ICS treatment;); (3) stratification of the severe uncontrolled asthma population, by biomarker levels; (4) identification and estimation of the sub-populations of severe uncontrolled asthma patients eligible for treatment with dupilumab, based on appropriate biomarker levels. The methodological approach flow is shown in Fig. 2.

\section{Data sources}

\section{Step 1}

To estimate the number of patients affected by asthma in Italy, a prevalence rate of $6.1 \%$ was used. This estimate was gathered from the 2016-2017 Italian-adapted GINA (Global Initiative for Asthma) guidelines [23], and refers to a recent study conducted by general practitioners in Italy, according to which 61 out of 1000 subjects aged $>15$ years old were presenting some form of asthma. In this study, prevalence rates were slightly higher for women (6.6\%) than for men (5.5\%) and tended to decrease with older age. This prevalence rate was considered appropriate to inform the analysis, because it was referred to a mixed population of adolescents and adults (i.e. patients aged $>15$ ), which is within the dupilumab approved indication (i.e. treatment of patients aged 12 and older). This prevalence rate was also consistent with GEIRD study estimates (prevalence rate of $6.6 \%$ in the Italian population aged 20-44 years old) [42]. The prevalence rate was then multiplied by the Italian population, aged $\geq 12$ years (source: Italian Institute of Statistics, ISTAT [43]).

\section{Step 2}

The second step of the analysis was to extract the population with severe uncontrolled asthma from the overall patient population with asthma. For this purpose, two different sources were used and then compared to each other: (1) a recent publication from Pedrini et al., 2017 [39]; (2) the analysis conducted by Region Veneto in 2016 (source: regional guidelines for pharmacological management of severe uncontrolled asthma [41]). The aim of both of these analyses was to identify and estimate patients with severe uncontrolled asthma, requiring follow-up in specialized hospital centers. In both cases, the analysis was conducted using Italian administrative claim databases as main data source.

In their study, Pedrini et al. retrospectively analysed administrative data concerning adult patients $(\geq 18$ years old) registered in an Italian healthcare system database (the Accounting and Reporting Console -ARCo- database) [39]. Over the 2013-2014 time period, patients with severe refractory asthma

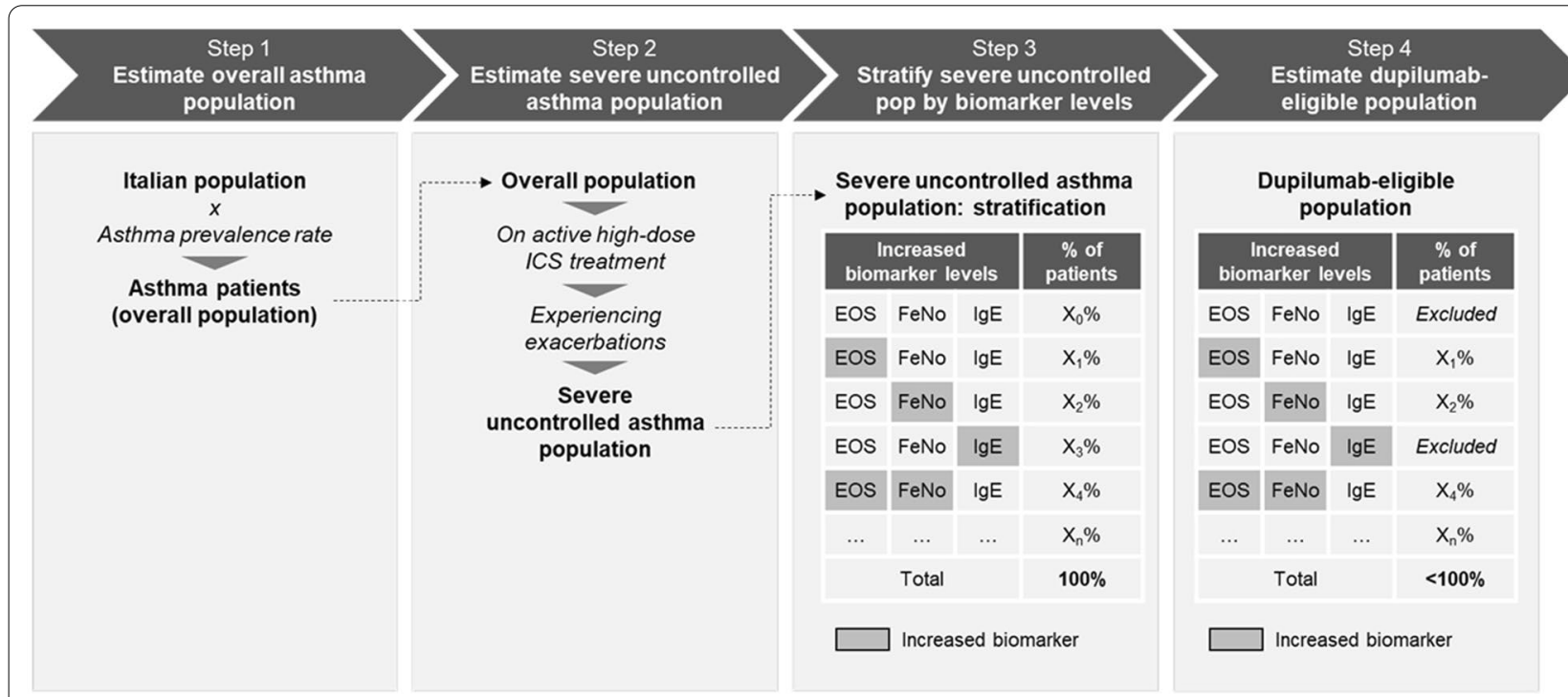

Fig. 2 Methodological approach to estimate dupilumab-eligible population in Italy (illustrative) 
were identified through: (1) prescription of omalizumab (anatomical therapeutic chemical -ATC- code: R03DX05) or; (2) asthma exemption code (007.493; it allows asthma patients to avoid participating in the cost of health services in Italy) associated with a prescription of high-dose systemic corticosteroids identifying asthma exacerbations (prednisone $25 \mathrm{mg}$, ATC code: H02AB07; or methylprednisolone $16 \mathrm{mg}$; ATC code: H02AB04); or (3) asthma exemption code (007.493) associated with outpatient service/day hospital with injection of other therapeutic or prophylactic substances (ICD9 CM procedure code: 99.29). With this approach, the authors estimated an overall prevalence of severe refractory asthma of $0.04 \%$.

The regional analysis conducted in Veneto adopted stricter requirements (compared with Pedrini et al.) to identify more appropriately patients with severe refractory asthma requiring regular specialist monitoring [41]. The analysis progressively filtered asthma patients through the following inclusion criteria: (1) asthma exemption code; (2) spirometry execution; (3) active pharmacological treatment with ICS + LABA, and/or theophylline and/or leukotriene receptor antagonists; (4) high-dose ICS treatment (prescription of ICS maximum dose); (5) high-rate adherence (level of annual coverage $\geq 80 \%$ ); (6) disease exacerbations ( $\geq 2$ episodes/year of inpatient admission or treatment with systemic corticosteroids for $>3$ days in the ambulatory setting). The codes considered for patient inclusion are reported in Additional File 1: TableS3. With this approach, the authors estimated an overall prevalence of severe refractory asthma of $0.034 \%$. The "patientfunnel" approach defined in this publication is shown in Table 1.

\section{Step 3}

The third step of the analysis was to stratify the severe uncontrolled asthma population by biomarker levels. Stratification of Type 2 asthma by biomarker status is important to identify patients with blood EOS $<150$ cells $/ \mu \mathrm{L}$ or $\mathrm{FeNO}<25 \mathrm{ppb}$, who must be excluded from patient estimation. For this purpose, the QUEST trial (a randomized, double-blind, placebo-controlled, parallel-group trial assessing the efficacy of dupilumab in patients with uncontrolled moderate-to-severe asthma; NCT02414854) was considered an appropriate source to evaluate the distribution of patients by Type 2 inflammation biomarkers: EOS, FeNO and IgE [29]. Figure 3 provides a graphical representation of patient distribution, by biomarker status, at baseline as per QUEST trial.

In general, the three largest groups were: (i) patients with increase of both EOS and FeNO levels (EOS $\geq 150$ cells $/ \mu \mathrm{L}$ and $\mathrm{FeNO} \geq 25 \mathrm{ppb}$ ) and allergic ( $\mathrm{IgE} \geq 30 \mathrm{IU} /$ $\mathrm{mL} ; 24.8 \%$ of patient population); (ii) patients with increase of both EOS and FeNO levels (EOS $\geq 150$ cells/ $\mu \mathrm{L}$ and $\mathrm{FeNO} \geq 25 \mathrm{ppb})$ and non-allergic $(\mathrm{IgE}<30 \mathrm{IU} / \mathrm{mL}$; $16.8 \%$ of patient population); (iii) patients with $\mathrm{EOS} \geq 150$ cells $/ \mu \mathrm{L}, \mathrm{FeNO}<25 \mathrm{ppb}$ and allergic $(\mathrm{IgE} \geq 30 \mathrm{IU} / \mathrm{mL}$; $16.7 \%$ of patient population).

\section{Step 4}

According to baseline patients' characteristics of the QUEST trial, two patient groups were considered noneligible to dupilumab: (i) patients with $\mathrm{EOS}<150$ cells/ $\mu \mathrm{L}, \mathrm{FeNO}<25 \mathrm{ppb}$ and allergic (IgE $\geq 30 \mathrm{IU} / \mathrm{mL} ; 10.5 \%$ of patient population); (ii) patients with $\mathrm{EOS}<150$ cells $/ \mu \mathrm{L}$, $\mathrm{FeNO}<25 \mathrm{ppb}$ and non-allergic ( $\mathrm{IgE}<30 \mathrm{IU} / \mathrm{mL} ; 9.4 \%$ of patient population). In conclusion, the QUEST trial indicates that $80.1 \%$ of patients with severe uncontrolled

Table 1 Estimation of patients with severe uncontrolled asthma in Italy

\begin{tabular}{|c|c|c|c|c|}
\hline$\#$ & Group of subjects & Estimation & $\begin{array}{l}\text { Number of subjects } \\
\text { (N) }\end{array}$ & Source \\
\hline 1 & Italian population, $\geq 12$ years & - & $5,41,19,490$ & ISTAT 2019 [43] \\
\hline 2 & Patients with asthma & $6.10 \%$ of \# 1 & $33,01,289$ & [41] \\
\hline 3 & Patients with asthma exemption code & $36.29 \%$ of \#2 & $11,97,821$ & \\
\hline 4 & Patients with spirometry (last 12 months) & $27.74 \%$ of \#3 & $3,32,281$ & \\
\hline 5 & Patients treated with ICS & $46.95 \%$ of \#4 & $1,55,997$ & \\
\hline 6 & Patients treated with high-dose ICS & $43.05 \%$ of \#5 & 67,151 & \\
\hline 7 & Patients treated with high-dose ICS, adherent & $57.20 \%$ of \#6 & 38,410 & \\
\hline 8 & Uncontrolled patients with $\geq 2$ exacerbations/year* & $47.57 \%$ of \#7 & 18,270 & \\
\hline 9 & Uncontrolled patients with severe asthma & $0.04 \%$ of \# 1 & 21,649 & [39] \\
\hline 10 & $\begin{array}{l}\text { Average number uncontrolled patients } \\
\text { with severe asthma }\end{array}$ & Average of \#8 and \#9 & 19,960 & Calculated \\
\hline
\end{tabular}

ICS inhaled corticosteroids, ISTAT italian institute of statistics

*Corresponding to $0.034 \%$ of the Italian population, $\geq 12$ years (\#1) 


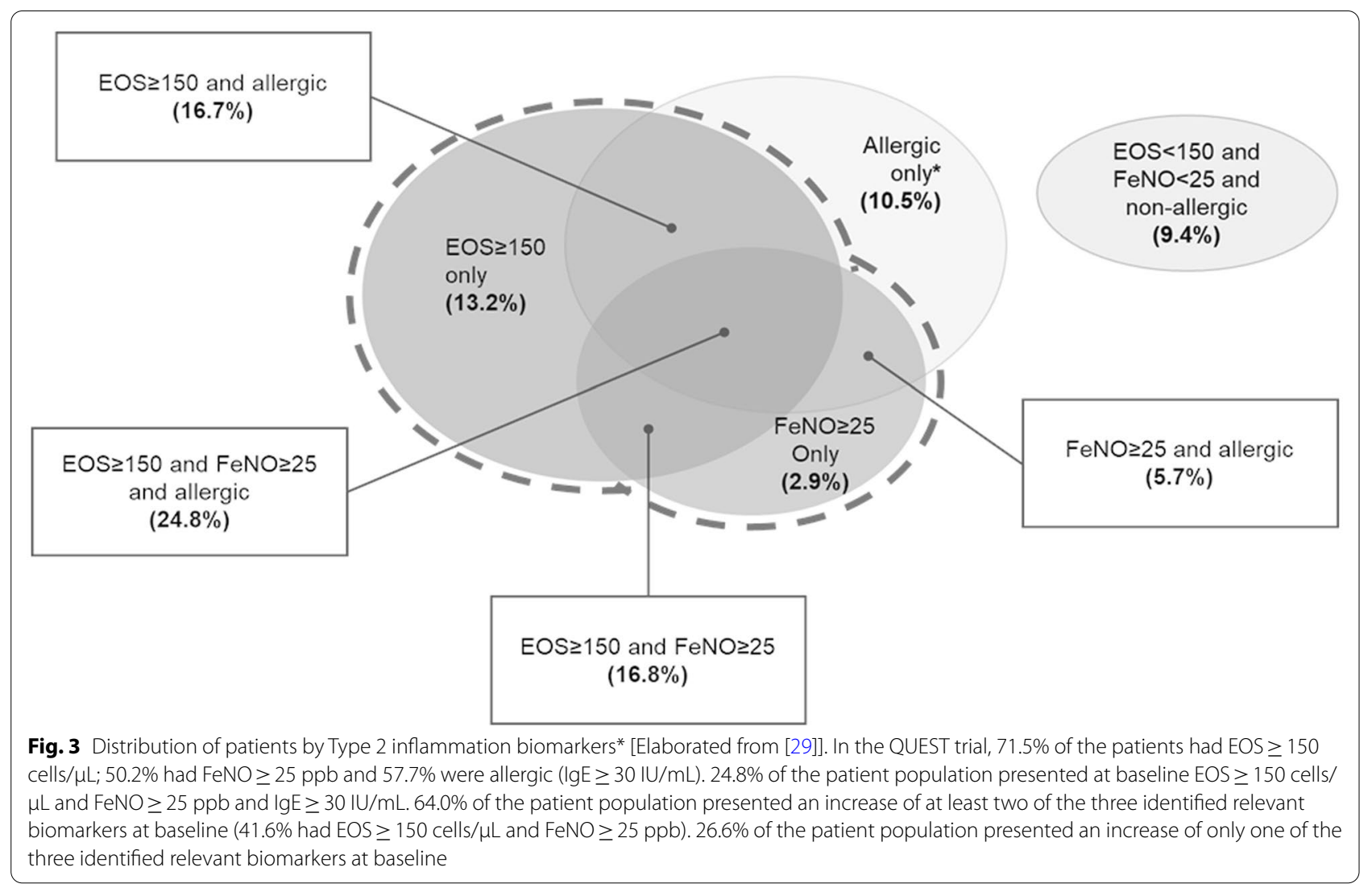

Type 2 asthma (100.0\%-10.5\%-9.4\%) would have raised blood EOS and/or raised FeNO and would be then eligible for dupilumab treatment.

\section{Results}

The input data collected through the 4-step approach were used to calculate the number of dupilumab-eligible patients. According to these estimates, about 3.3 million asthmatic subjects live in Italy (Table 1 ; line 2). If findings of the analysis conducted in Veneto are reproportioned to Italy, we would expect that 330 thousand patients with asthma receive at least one spirometry per year $(10 \%$ of the overall population), and almost half of them $(\sim 156$ thousand) receive some treatment with ICS. A small, but non-negligible proportion of these patients, between $0.034 \%$ and $0.04 \%$, are affected by uncontrolled asthma, resulting into $\mathrm{N}=18,270-21,649$ patients (Table 1 , lines 8 and 9 , respectively).

On average, the number of patients with QUESTlike characteristics would be $N=19,960$. This number accounts for $\sim 6 \%$ of all asthmatic patients who receive some regular follow up (i.e. patients with spirometry) and $13 \%$ of all actively treated asthmatic patients (i.e. patients receiving ICS).
Table 2 provides stratification of the $\mathrm{N}=19,960$ Italian patients, if their characteristics were comparable to those of the QUEST patients at baseline. Most patients $(\mathrm{N}=12,774 ; 64.0 \%=$ groups $1,2,3,4)$ would have $\geq 2$ raised biomarkers and almost one out of four patients $(\mathrm{N}=4950$ in total) would have EOS, FeNO and IgE raised levels simultaneously. Dupilumab-eligible patients would be $\mathrm{N}=15,988$, corresponding to $80.1 \%$ of the target population.

Finally, Fig. 4 provides an overview of the dupilumabeligible Italian patient population by EOS and FeNO levels, with further stratification by presence of allergic disease $(\operatorname{IgE} \geq 30 \mathrm{IU} / \mathrm{mL})$. More than half eligible patients $(\mathrm{N}=8303)$ present raised levels of both biomarkers, while the large majority $(89.3 \%)$ has at least an increase of EOS levels $(\mathrm{N}=14,271)$. Increased FeNO levels without increased EOS are observed less frequently $(\mathrm{N}=1717 ; 10.7 \%$ of the eligible population). In all the three subgroups, there are more allergic (i.e. $\mathrm{IgE} \geq 30 \mathrm{IU} / \mathrm{mL}$ ) than non-allergic patients $(59.6 \%$ in the both EOS and FeNO raised group; $55.9 \%$ in the only EOS raised group; $66.3 \%$ in the only FeNO group). In total, $58.9 \%$ of the dupilumab-eligible patient population would also have concomitantly high IgE levels $(\mathrm{N}=9421)$. 
Table 2 Estimation of patients with severe uncontrolled asthma in Italy, by dupilumab eligibility [29]

\begin{tabular}{|c|c|c|c|c|c|c|c|}
\hline \# & Patient subgroup $^{\circ}$ & $\begin{array}{l}\text { Proportion } \\
\text { of pts (\%) }\end{array}$ & $\begin{array}{l}\mathrm{EOS} \geq 150 \\
\text { cells } / \mu \mathrm{L}\end{array}$ & FeNO $\geq 25 \mathrm{ppb}$ & $\lg \mathrm{E} \geq 30 \mathrm{IU} / \mathrm{mL}^{*}$ & $\begin{array}{l}\text { Dupilumab- } \\
\text { eligible }\end{array}$ & $\begin{array}{l}\text { Number of } \\
\text { eligible pts } \\
\text { (N) }\end{array}$ \\
\hline- & All patients & $100.0 \%$ & $n / a$ & $n / a$ & $n / a$ & $n / a$ & 19,960 \\
\hline 1 & $\begin{array}{l}\mathrm{EOS} \geq 150 \text { cells } / \mu \mathrm{L} \text { and } \mathrm{FeNO} \geq 25 \mathrm{ppb} \text { and } \\
\operatorname{lgE} \geq 30 \mathrm{IU} / \mathrm{mL}\end{array}$ & $24.8 \%$ & $\checkmark$ & $\checkmark$ & $\checkmark$ & Yes & 4950 \\
\hline 2 & $\begin{array}{l}\mathrm{EOS} \geq 150 \text { cells/ } \mu \mathrm{L} \text { and FeNO }<25 \mathrm{ppb} \text { and } \\
\operatorname{lgE} \geq 30 \mathrm{IU} / \mathrm{mL}\end{array}$ & $16.7 \%$ & $\checkmark$ & & $\checkmark$ & Yes & 3333 \\
\hline 3 & $\begin{array}{l}\mathrm{EOS}<150 \mathrm{cells} / \mu \mathrm{L} \text { and } \mathrm{FeNO} \geq \mathbf{2 5} \mathbf{p p b} \text { and } \\
\operatorname{lgE} \geq 30 \mathrm{IU} / \mathrm{mL}\end{array}$ & $5.7 \%$ & & $\checkmark$ & $\checkmark$ & Yes & 1138 \\
\hline 4 & $\begin{array}{l}\mathrm{EOS} \geq 150 \text { cells } / \mu \mathrm{L} \text { and } \mathrm{FeNO} \geq 25 \mathrm{ppb} \text { and } \\
\mathrm{lgE}<30 \mathrm{IU} / \mathrm{mL}\end{array}$ & $16.8 \%$ & $\checkmark$ & $\checkmark$ & & Yes & 3353 \\
\hline 5 & $\begin{array}{l}\mathrm{EOS} \geq 150 \text { cells } / \mu \mathrm{L} \text { and } \mathrm{FeNO}<25 \mathrm{ppb} \text { and } \\
\operatorname{lgE}<30 \mathrm{IU} / \mathrm{mL}\end{array}$ & $13.2 \%$ & $\checkmark$ & & & Yes & 2635 \\
\hline 6 & $\begin{array}{l}\mathrm{EOS}<150 \mathrm{cell} / \mathrm{s} / \mu \mathrm{L} \text { and } \mathrm{FeNO} \geq \mathbf{2 5} \mathbf{p p b} \text { and } \\
\operatorname{lgE}<30 \mathrm{IU} / \mathrm{mL}\end{array}$ & $2.9 \%$ & & $\checkmark$ & & Yes & 579 \\
\hline 7 & $\begin{array}{l}\mathrm{EOS}<150 \mathrm{cell} / \mathrm{s} / \mathrm{\mu L} \text { and FeNO }<25 \mathrm{ppb} \text { and } \\
\operatorname{lgE} \geq 30 \mathrm{IU} / \mathrm{mL}\end{array}$ & $(10.5 \%)$ & & & $\checkmark$ & No & (2096) \\
\hline 8 & 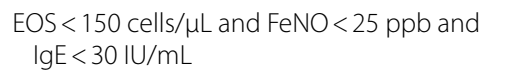 & $(9.4 \%)$ & & & & No & $(1876)$ \\
\hline- & All dupilumab-eligible patients & $80.1 \%$ & $n / a$ & $n / a$ & $n / a$ & Yes & 15,988 \\
\hline
\end{tabular}

EOS eosinophils, FeNO fractional exhaled nitric oxide, $I g E$ immunoglobulin $E, n / a$ not available, pts patients

${ }^{\circ}$ Biomarkers of interest (EOS $\geq 150$ cells/ $\mu \mathrm{L}$ and FeNO $\geq 25 \mathrm{ppb}$ ) are indicated in bold. *IgE biomarker was evaluated in the QUEST trial; however, IgE alone is not a biomarker to define eligibility for dupilumab. (dupilumab is indicated in Type 2 asthma patients, characterized by raised blood eosinophils and/or raised fractional exhaled nitric oxide, regardless of IgE levels)

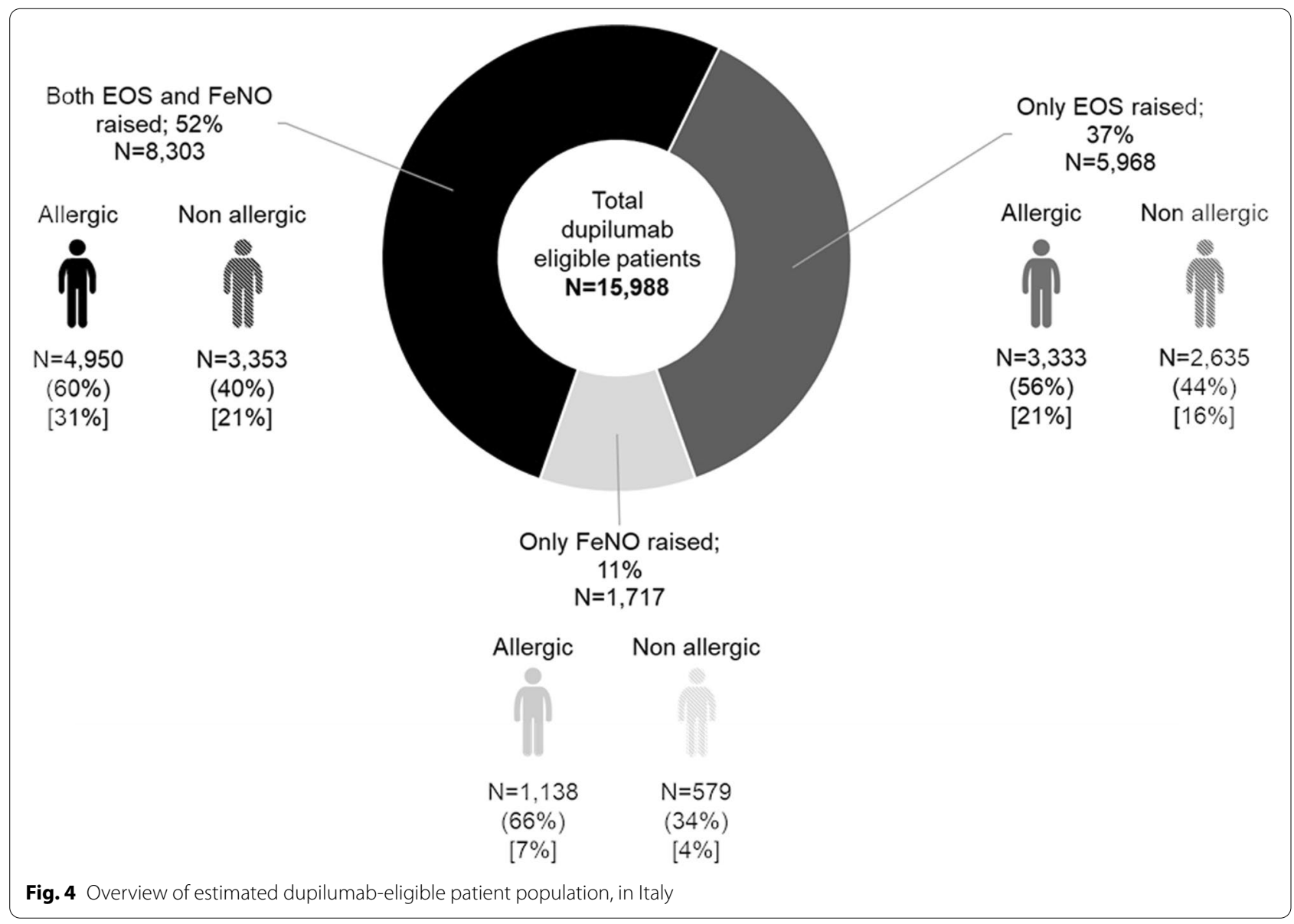




\section{Discussion}

The present analysis is an attempt to estimate the epidemiological burden of asthma, and to characterize patient population by severity, type of inflammation and expected distribution of biomarker levels in severe patients. We used data from the QUEST trial to estimate the number of patients with raised EOS and/or raised FeNO to identify the subgroup of patients that would be eligible for dupilumab treatment. The recent administrative database analyses $[39,41]$ were considered valid tools to estimate the general prevalence of asthma and the proportion of severe cases in Italy. However, a large difference between the registry-based and the administrative-based prevalence rates exists. While the general prevalence of asthma among children and adults is about $6 \%-7 \%$ [23], only $2 \%$ of this patient population has an exemption code for asthma [41], meaning that the remaining $4 \%-5 \%$ of patients have very mild forms of asthma and do not consume the same high level of healthcare resources on a regular basis. Interestingly, the two administrative database analyses estimated a similar proportion of patients with severe uncontrolled asthma (i.e. patients with exacerbations requiring hospital care and/or specialized follow-up): $0.04 \%$ in the Pedrini et al. study [39] and $0.034 \%$ in the Veneto study [41].

Finally, these analyses showed that patients with severe uncontrolled asthma would be $\sim 6 \%$ of all asthmatic patients who receive some regular follow up (i.e. patients with spirometry) and $13 \%$ of all actively treated asthmatic patients (i.e. patients receiving ICS). These figures are quite consistent with published literature, concluding that $5 \%-10 \%$ of patients have a severe form of asthma which is refractory to conventional steroid medical therapy [9].

The QUEST study [29] was used as source to stratify patients with uncontrolled asthma by biomarker levels since it is the only RCT that recruited severe asthmatic patients regardless of minimum baseline blood EOS count or other Type 2 inflammation biomarkers. We chose to use a clinical trial source, rather than a local publication (e.g. the analysis conducted by Heffler et al. [40]), because to our knowledge, QUEST is the only large clinical study providing a complete overview of asthmatic patients subpopulations by Type 2 single biomarker level (i.e. raised EOS, FeNO or IgE) and by grouped biomarkers (e.g. patients with both increased EOS and FeNO level; patients with increased EOS and normal FeNO level, etc.).

Patient distributions, by individual biomarker levels at baseline, were consistent in the QUEST [29] and the SANI (Severe Asthma Network in Italy) cohorts. SANI is an Italian National Registry, promoted by GINA ItalySIAAIC (Italian Society of Allergy, Asthma and Clinical
Immunology) and SIP/IRS (Italian Respiratory Society), which enrolled patients with severe asthma in a real life setting [44]. For instance, the proportion of patients with $\mathrm{EOS} \geq 150$ cells $/ \mu \mathrm{L}$ was $71.5 \%$ in the QUEST trial (Table 2), and $79.8 \%$ in the SANI registry, thus confirming EOS as the most prevalent biomarker among uncontrolled asthma patients. With regards of FeNO, 50.2\% of patients had raised levels (FeNO $\geq 25 \mathrm{ppb})$ in the QUEST trial, and $50.1 \%$ of patients in the SANI registry. In both studies, high proportions of patients were found to have comorbidities such as atopic and nasal polyposis or chronic rhinosinusitis. In the QUEST study, 23.0\% of patients had nasal polyposis, $10.3 \%$ had atopic dermatitis and $68.6 \%$ had allergic rhinitis [29]. In the SANI study, $42.6 \%, 9.6 \%$ and $44.6 \%$ of patients had respectively nasal polyposis, atopic dermatitis and allergic rhinitis [40].

According to our estimates, about 20 thousand patients with severe uncontrolled asthma live in Italy, and about 16 thousand patients $(\sim 80 \%)$ have a Type 2 endotype with raised EOS and/or FeNO, who would make them potentially eligible to dupilumab. Whilst most of dupilumab-eligible patients demonstrate raised EOS level $(\mathrm{N}=14,271,89.3 \%)$, there is still a non-negligible number of patients $(\mathrm{N}=1717,10.7 \%$ of the eligible population) that have increased FeNO levels without increased EOS. This suggests the importance of testing both the biomarkers, during the diagnosis of Type 2 asthma and in the disease follow-up. Indeed, some patients may have clinically uncontrolled asthma but the biomarker expression could be suppressed by pharmacological treatment [1]. Moreover, according to GINA guidelines, the efficacy of the severe asthma therapy must be evaluated through disease control (reduction in exacerbation, improvement in lung function, oral corticosteroids use reduction, etc.) rather than reduction of biomarkers levels [45].

Plausibly, there are a few methodological limitations in this analysis, that might affect validity of findings and increase uncertainty of the estimates. First, we used administrative database analyses, rather than clinical registry data, to estimate the overall population with uncontrolled asthma. This might lead to underestimation of patients, as administrative databases do not identify patients: (i) seeking private care; (ii) with intermittent disease, who would temporarily be "out of the system" but would likely reappear later in time. It is estimated that $5 \%-10 \%$ of all asthma patients develop severe refractory disease $[46,47]$. The estimate presented here represents the patient population with uncontrolled severe asthma, despite adequate therapy compliance. Therefore, there is a risk that such methodology would include the population with the highest medical need and exclude milder forms that will exacerbate later. However, we believe that such an estimate would still be more precise and accurate 
than registry-based assessments, which are based on much smaller sample sizes and would tend to overestimate eligible patients. A second limitation of the analysis is the use of clinical trial data (i.e. QUEST) to stratify the asthma population by biomarker levels. QUEST data were preferred over real-practice Italian data due to their completeness but might not be representative of the local situation. However, some of the possible comparisons between QUEST and SANI cohorts showed a good level of consistency between the two sources, suggesting that our choice of using QUEST data was methodologically acceptable.

According to GINA guidelines, clinical assessment of severe asthma is a crucial step for disease characterization, as it ensures identification of patients requiring urgent healthcare interventions and highly effective treatments. Biomarker assessment is essential to identify the expression of Type 2 inflammation. According to GINA guidelines and prescribing conditions defined by regulatory agencies, the increase of at least one of the severe Type 2 asthma biomarkers would justify the use of biological therapy. However, in clinical practice, it is important to understand the complexity of the inflammatory mechanisms of Type 2 inflammation for each patient, to choose the treatment with the highest probability of acting against the different Type 2 inflammatory components expressed or co-expressed by the patient. Testing for more biomarkers simultaneously, is strongly recommended during baseline patient assessment and disease follow-up, to identify the possible targets of biological therapy (EOS, IgE, FeNO). As a matter of fact, patients with normal EOS but increased FeNO have similar disease severity (i.e. same forced expiratory volume -FEV1-, exacerbation rate and asthma control questionnaire score -ACQ-) as patients with raised EOS and normal FeNO, or patients with both raised EOS and FeNO. In a post-hoc analysis of the QUEST study [36], the efficacy of dupilumab was assessed by biomarker subgroups, as defined by GINA. Baseline blood EOS count and FeNO levels clearly showed that disease severity was similar in all sub-populations (only EOS $\geq 150$ cells/ $\mu \mathrm{L}$, only $\mathrm{FeNO} \geq 20 \mathrm{ppb}$, both $\mathrm{EOS} \geq 150$ cells $/ \mu \mathrm{L}$ and FeNO $\geq 20 \mathrm{ppb}$ ) at baseline [48]. Therefore, testing different biomarkers simultaneously during disease followup is strongly recommended, to monitor the different inflammatory components of Type 2 inflammation and evaluate adjustment of the biological treatment.

\section{Conclusions}

In conclusion, it was possible to estimate the number of dupilumab-eligible patients in Italy, using data on clinical assessment and biomarker testing from local studies and QUEST trial (EOS and/or FeNO, $\mathrm{N}=15,988,80.1 \%$ of patients with severe uncontrolled asthma). There is a strong rationale for simultaneously biomarker testing (including FeNO) during diagnosis and diseases followup. With relatively low-cost tests, physicians can estimate the number of patients with severe asthma with Type 2 inflammation (Type 2 asthma), stratify them by phenotypes (eosinophilic, allergic, or mixed), identify the optimal treatment strategy and prescribe biologic therapy appropriately.

\section{Abbreviations \\ ACQ: Asthma control questionnaire score; AHR: Airway hyperresponsive- ness; ARCO: Accounting and reporting console; ATC: Anatomical therapeutic chemical; EMA: European medicines agency; EOS: Eosinophils; FeNO: Fraction of exhaled nitric oxide; FEV: Forced expiratory volume; GINA: Global initiative for asthma; ICD: International classification of diseases; ICS: Inhaled corticos- teroids; IgE: Immunoglobulin-E; IL: Interleukin; ILC: Innate lymphoid cells; iNO: Inducible nitric oxide; ISTAT: Italian institute of statistics; LABA: Long-acting B2-adrenoreceptor agonists; LTRAs: Cysteinyl-leukotriene type 1 receptor antagonists; n/a: Not available; NO: Nitric oxide; pts: Patients; RCT: Randomized Controlled Trial; SANI: Severe Asthma Network In Italy; SIAAIC: Italian society of allergy, asthma and clinical immunology; SIP/IRS: Italian respiratory society; Th2: T-Helper cell type 2 .}

\section{Supplementary Information}

The online version contains supplementary material available at https://doi. org/10.1186/s12948-021-00146-9.

Additional file1 :Table S3. Codes considered for patient inclusion in the Veneto study [41].

\section{Acknowledgements}

Not applicable.

Authors' contributions

All authors read and approved the final manuscript.

Funding

Sanofi S.p.A. provided funding for the editorial support of this article.

Availability of data and materials

All data generated or analysed during this study are included in this published article.

\section{Declarations}

Ethics approval and consent to participate Not applicable.

\section{Consent for publication}

Not applicable.

\section{Competing interests}

GF (EBMA Consulting SRL) received consulting fees from Sanofi SpA for conducting the analysis.

\section{Author details}

'Personalized Medicine, Asthma and Allergy, Humanitas Clinical and Research Center IRCCS, Via Manzoni 56, 20089 Rozzano, MI, Italy. ${ }^{2}$ Department of Biomedical Sciences, Humanitas University, Pieve Emanuele, MI, Italy. ${ }^{3}$ Fondazione IRCCS Ca Granda Ospedale Maggiore Policlinico, Internal Medicine Department, Respiratory Unit and Cystic Fibrosis Adult Center and Department of Pathophysiology and Transplantation, University of Milan, Milan, Italy. 


\begin{abstract}
${ }^{4}$ Respiratory Medicine Unit, A.O.U. Policlinico-Vittorio Emanuele, Catania, Italy. ${ }^{5}$ Department of Clinical and Experimental Medicine, University of Catania, Catania, Italy. ${ }^{6}$ Department of Surgery, Medicine, Molecular Biology and Critical Care, University of Pisa, Pisa, Italy. ${ }^{7}$ Respiratory Medicine Unit, Department of Medical Sciences, University of Ferrara, Ferrara, Italy. ${ }^{8}$ Sanofi S.P.A., Milan, Italy. ${ }^{9}$ EBMA Consulting S.R.L., Via per Carpiano 2, 20077 Melegnano, MI, Italy.
\end{abstract}

Received: 16 July 2020 Accepted: 10 May 2021

Published online: 21 May 2021

\section{References}

1. Global Initiative for Asthma (GINA). Global strategy for Asthma management and prevention 2019. https://ginasthma.org/wp-content/uploads/ 2019/06/GINA-2019-main-report-June-2019-wms.pdf.

2. Holgate ST, Wenzel S, Postma DS, Weiss ST, Renz H, Sly PD. Asthma. Nat Rev Dis Prim. 2015;1:15025. https://doi.org/10.1038/nrdp.2015.25.

3. Masoli M, Fabian D, Holt S, Beasley R. The global burden of asthma executive summary of the GINA dissemination committee report. Allergy. 2004. https://doi.org/10.1111/j.1398-9995.2004.00526.x.

4. Chanez P, Humbert M. Asthma: still a promising future? Eur Respir Rev. 2014. https://doi.org/10.1183/09059180.00009614.

5. Global Asthma Network. The Global Asthma Report, Auckland, New Zealand. 2018

6. Dharmage SC, Perret JL, Custovic A. Epidemiology of asthma in children and adults. Front Pediatr. 2019;7:1-15. https://doi.org/10.3389/fped.2019. 00246.

7. Kuruvilla ME, Lee FEH, Lee GB. Understanding Asthma Phenotypes, Endotypes, and Mechanisms of Disease. Clin Rev Allergy Immunol. 2019;56:219-33. https://doi.org/10.1007/s12016-018-8712-1.

8. Fahy JV. Type 2 inflammation in asthma-present in most, absent in many. Nat Rev Immunol. 2015. https://doi.org/10.1038/nri3786.

9. Santini G, Mores N, Malerba M, Mondino C, Anzivino R, Macis G, et al. Dupilumab for the treatment of asthma. Expert Opin Investig Drugs. 2017;26:357-66. https://doi.org/10.1080/13543784.2017.1282458.

10. Seys SF, Scheers H, Van den Brande P, Marijsse G, Dilissen E, Van Den Bergh A, et al. Cluster analysis of sputum cytokine-high profiles reveals diversity in T(h)2-high asthma patients. Respir Res. 2017;18:39. https://doi. org/10.1186/s12931-017-0524-y.

11. Peters MC, Mekonnen ZK, Yuan S, Bhakta NR, Woodruff PG, Fahy JV. Measures of gene expression in sputum cells can identify TH2-high and TH2-low subtypes of asthma. J Allergy Clin Immunol. 2014;133:388-94. https://doi.org/10.1016/j.jaci.2013.07.036.

12. Robinson D, Humbert $M$, Buhl R, Cruz AA, Inoue H, Korom S, et al. Revisiting type 2-high and type 2-low airway inflammation in asthma: current knowledge and therapeutic implications. Clin Exp Allergy. 2017. https:// doi.org/10.1111/cea.12880.

13. Gandhi NA, Pirozzi G, Graham NMH. Commonality of the IL-4/IL-13 pathway in atopic diseases. Expert Rev Clin Immunol. 2017. https://doi.org/10 1080/1744666X.2017.1298443.

14. Tiotiu A. Biomarkers in asthma: state of the art. Asthma Res Pract. 2018. https://doi.org/10.1186/s40733-018-0047-4.

15. Castro M, Wenzel SE, Bleecker ER, Pizzichini E, Kuna P, Busse WW, et al. Benralizumab, an anti-interleukin 5 receptor a monoclonal antibody, versus placebo for uncontrolled eosinophilic asthma: a phase $2 \mathrm{~b}$ randomised dose-ranging study. Lancet Respir Med. 2014;2:879-90. https:// doi.org/10.1016/S2213-2600(14)70201-2.

16. Pavord ID, Korn S, Howarth P, Bleecker ER, Buhl R, Keene ON, et al. Mepolizumab for severe eosinophilic asthma (DREAM): a multicentre, doubleblind, placebo-controlled trial. Lancet. 2012;380:651-9. https://doi.org/10. 1016/S0140-6736(12)60988-X

17. Wenzel S, Ford L, Pearlman D, Spector S, Sher L, Skobieranda F, et al. Dupilumab in persistent asthma with elevated eosinophil levels. N Engl J Med. 2013;368:2455-66. https://doi.org/10.1056/NEJMoa1304048.

18. Hanania NA, Wenzel S, Rosen K, Hsieh H-J, Mosesova S, Choy DF, Lal P, Arron JR, Harris JM, Busse W. Exploring the effects of omalizumab in allergic asthma: an analysis of biomarkers in the EXTRA study. Am J Respir Crit Care Med. 2013;187:804-11.
19. Global Initiative for Asthma (GINA). Global strategy for Asthma management and prevention 2019. https://ginasthma.org/wp-content/uploads/ 2020/04/GINA-2020-full-report_-final-_wms.pdf.

20. Gandhi NA, Bennett BL, Graham NMH, Pirozzi G, Stahl N, Yancopoulos GD. Targeting key proximal drivers of type 2 inflammation in disease. Nat Rev Drug Discov. 2016;15:35-50. https://doi.org/10.1038/nrd4624.

21. Matsusaka M, Fukunaga K, Kabata H, Izuhara K, Asano K, Betsuyaku T. Subphenotypes of type 2 severe asthma in adults. J Allergy Clin Immunol Pract. 2018:6:274-6.e2. https://doi.org/10.1016/j.jaip.2017.06.015.

22. Spahn JD, Malka J, Szefler SJ. Current application of exhaled nitric oxide in clinical practice. J Allergy Clin Immunol. 2016. https://doi.org/10.1016/j. jaci.2016.09.002.

23. LINEE GUIDA GINA ITALIANE Versione 2016-2017. http://ginasma.it/wpcontent/uploads/materiali/2017/GINA_adattamento_ita_2017_doc.pdf

24. Chung KF, Wenzel SE, Brozek JL, Bush A, Castro M, Sterk PJ, et al. International ERS/ATS quidelines on definition, evaluation and treatment of severe asthma. Eur Respir J. 2014;43:343-73. https://doi.org/10.1183/ 09031936.00202013.

25. Demoly P, Annunziata K, Gubba E, Adamek L. Repeated cross-sectional survey of patient-reported asthma control in europe in the past 5 years. Eur Respir Rev. 2012;21:66-74. https://doi.org/10.1183/09059180.00008 111.

26. Boulet L. Influence of comorbid conditions on asthma. Eur Respir J. 2009:33:897-906. https://doi.org/10.1183/09031936.00121308.

27. Godar M, Blanchetot C, de Haard H, Lambrecht BN, Brusselle G. Personalized medicine with biologics for severe type 2 asthma: current status and future prospects. MAbs. 2018;10:34-5. https://doi.org/10.1080/19420862. 2017.1392425.

28. Rabe KF, Nair P, Brusselle G, Maspero JF, Castro M, Sher L, et al. Efficacy and safety of dupilumab in glucocorticoid-dependent severe asthma. N Engl J Med. 2018:378:2475-85. https://doi.org/10.1056/NEJMoa1804093.

29. Castro M, Corren J, Pavord ID, Maspero J, Wenzel S, Rabe KF, et al. Dupilumab efficacy and safety in moderate-to-severe uncontrolled asthma. N Engl J Med. 2018. https://doi.org/10.1056/NEJMoa1804092.

30. Wenzel S, Castro M, Corren J, Maspero J, Wang L, Zhang B, et al. Dupilumab efficacy and safety in adults with uncontrolled persistent asthma despite use of medium-to-high-dose inhaled corticosteroids plus a long-acting $\beta 2$ agonist: a randomised double-blind placebo-controlled pivotal phase 2 b dose-ranging trial. Lancet. 2016. https://doi.org/10. 1016/S0140-6736(16)30307-5.

31. European Medicine Agency (EMA). Summary of product characteristics. Dupixent (Dupilumab). https://www.ema.europa.eu/en/documents/ product-information/dupixent-epar-product-information_en.pdf.

32. Agenzia Europea per i Medicinali (EMA). Nucala (Mepolizumab). Riassunto delle caratteristiche del prodotto, https://www.ema.europa.eu/en/ documents/product-information/nucala-epar-product-information_en. pdf (Ultimo accesso: 01/12/2018).

33. Agenzia Europea per i Medicinali (EMA). Xolair (Omalizumab). Riassunto delle caratteristiche del prodotto, https://www.ema.europa.eu/en/ documents/product-information/xolair-epar-product-information_en. pdf (Ultimo accesso: 01/12/2018).

34. Agenzia Europea dei Medicinali (EMA). Cinqaero (Reslizumab). Riassunto caratteristiche del prodotto. https://www.ema.europa.eu/en/documents/ product-information/cinqaero-epar-product-information_it.pdf.

35. Agenzia Europea per i Medicinali (EMA). Dupixent (Dupilumab). Riassunto caratteristiche prodotto, http://www.ema.europa.eu/docs/en_GB/docum ent_library/EPAR_-_Product_Information/human/004390/WC500236507. pdf. (Ultimo accesso: 01/12/2018).

36. Agenzia Europea per i Medicinali (EMA). Fasenra (Benralizumab). Riassunto delle caratteristiche del prodotto, https://www.ema.europa.eu/en/ documents/product-information/fasenra-epar-product-information_en. pdf (Ultimo accesso: 01/12/2018)

37. Pelaia C, Vatrella A, Gallelli L, Terracciano R, Navalesi P, Maselli R, et al. Dupilumab for the treatment of asthma. Expert Opin Biol Ther 2017;17:1565-72. https://doi.org/10.1080/14712598.2017.1387245.

38. Accordini S, Corsico AG, Braggion M, Gerbase MW, Gislason D, Gulsvik A, et al. The cost of persistent asthma in Europe: an International population-based study in adults. Int Arch Allergy Immunol. 2013;160:93-101. https://doi.org/10.1159/000338998.

39. Pedrini A, Rossi E, Calabria S, Dondi L, Martini N. Current management of severe refractory asthma in italy: analysis of real-world data. Glob Reg 
Heal Technol Assess Ital North Eur Spanish. 2017;4:grhta.5000273. https:// doi.org/10.5301/grhta.5000273.

40. Heffler E, Blasi F, Latorre M, Menzella F, Paggiaro P, Pelaia G, et al. The severe asthma network in italy: findings and perspectives. J Allergy Clin Immunol Pract. 2018. https://doi.org/10.1016/J.JAIP.2018.10.016.

41. Region Veneto. Regional analysis of patients with severe uncontrolled asthma, with exemption code 007 , requiring monitoring in a specialized center. Decree N. 54, attachment A, April 2018.

42. De Marco R, Cappa V, Accordini S, Rava M, Antonicelli L, Bortolami O, et al. Trends in the prevalence of asthma and allergic rhinitis in Italy between 1991 and 2010. Eur Respir J. 2012;39:883-92. https://doi.org/10.1183/ 09031936.00061611.

43. Italian Institute of Statistics (ISTAT). Italian population (2019). http://dati. istat.it/. Accessed 15 Apr 2020.

44. Senna G, Guerriero M, Paggiaro PL, Blasi F, Caminati M, Heffler E, et al. SANI-Severe Asthma Network in Italy: a way forward to monitor severe asthma. Clin Mol Allergy. 2017. https://doi.org/10.1186/ s12948-017-0065-4.

45. Le Floc'h A, Allinne J, Nagashima K, Scott G, Birchard D, Asrat S, et al. Dual blockade of IL-4 and IL-13 with dupilumab, an IL-4Ra antibody, is required to broadly inhibit type 2 inflammation. Allergy. 2020. https://doi.org/10. 1111/all.14151.

46. O'Byrne PM, Naji N, Gauvreau GM. Severe asthma: future treatments. Clin Exp Allergy. 2012;42:706-11. https://doi.org/10.1111/j.1365-2222.2012. 03965.X.

47. Pakhale S, Mulpuru S, Boyd M. Optimal management of severe/refractory asthma. Clin Med Insights Circ Respir Pulm Med. 2011. https://doi.org/10. 4137/CCRPM.S5535.

48. Pavord ID, Fitzgerald JM, Brusselle G, Wenzel SE, Rabe KF, Busse WW, et al. Dupilumab Efficacy in Type 2 Inflammatory Asthma: Liberty Asthma QUEST Study. 2019; https://doi.org/10.1183/13993003.congress-2019. oa3807

\section{Publisher's Note}

Springer Nature remains neutral with regard to jurisdictional claims in published maps and institutional affiliations.
Ready to submit your research? Choose BMC and benefit from:

- fast, convenient online submission

- thorough peer review by experienced researchers in your field

- rapid publication on acceptance

- support for research data, including large and complex data types

- gold Open Access which fosters wider collaboration and increased citations

- maximum visibility for your research: over $100 \mathrm{M}$ website views per year

At BMC, research is always in progress.

Learn more biomedcentral.com/submissions 